Article

\title{
Impact of Electric Bus Charging on Distribution Substation and Local Grid in Warsaw
}

\author{
Krzysztof Zagrajek *iD, Józef Paska, Mariusz Kłos, Karol Pawlak, Piotr Marchel, \\ Magdalena Bartecka ${ }^{D}$, Łukasz Michalski and Paweł Terlikowski
}

Institute of Electrical Power Engineering, Warsaw University of Technology, str. Koszykowa 75, 00-662 Warsaw, Poland; jozef.paska@ien.pw.edu.pl (J.P.); mariusz.klos@ien.pw.edu.pl (M.K.); karol.pawlak@ien.pw.edu.pl (K.P.); piotr.marchel@ien.pw.edu.pl (P.M.); magdalena.bledzinska@ien.pw.edu.pl (M.B.);

lukasz.michalski@ien.pw.edu.pl (Ł.M.); pawel.terlikowski@ien.pw.edu.pl (P.T.)

* Correspondence: krzysztof.zagrajek@ien.pw.edu.pl

Received: 12 February 2020; Accepted: 5 March 2020; Published: 5 March 2020

check for updates

\begin{abstract}
Electric buses are increasingly appearing on the streets of cities around the world. Thus, it is necessary to consider the impact of their charging on the distribution system operation, especially near the charging point. This article presents the problems that may arise while new charging points are connected. Research was carried out on the existing charging point at Spartańska Street in Warsaw, which allowed to obtain daily bus charging profiles and voltage curves. The authors then proposed an exemplary model of a bus terminus with the designed infrastructure for charging buses, based on the assumptions of the public transport operator in Warsaw. The comparison of these two solutions was made and based on it, a methodology of calculating daily demand for any terminus was prepared. In addition, no problems with the power quality were found during the research. This allows us to state that the introduction of electric buses into the fleet of passenger carriers will have a minor impact on the operation of the power system in Warsaw.
\end{abstract}

Keywords: electric buses; distribution grid; public transport; electromobility; power system; smart city

\section{Introduction}

Electrification of public bus transport has been presented in the public space for several decades. The precursors of electric buses were trolleybuses. However, those vehicles have some disadvantages including: a high cost of network maintenance and low mobility and operational flexibility. Trolleybuses have therefore been preserved in very few cities in Europe. Modern designs of electric buses (EB) began to appear more frequently in the first decade of the 21st century. Among others, China, the USA and many other European Union countries decided to buy electric buses. Based on current research [1], it can be concluded that the total number of electric buses at the end of 2017 amounted to approximately 370,000 globally. China is the leader in introducing electric buses [1]. Great interest in the electric bus market is progressing along with growing social awareness of environmental protection [2]. Electric buses have a number of advantages, including being zero-emission vehicles at their place of use [3] and also, they do not emit any noise associated with engine operation [4-6]. Those advantages are the reason that they are willingly considered by the municipal authorities to operate in tourist zones. However, it should be remembered that electric buses also have disadvantages, such as a high price and the need to provide infrastructure for charging, which is linked with high capital investment in the process of implementing electric buses in cities [7].

The introduction of electric buses to the fleet of urban transport companies is a demanding challenge for both urban transport operators and energy companies-Distribution System Operators (DSO). Urban transport operators have to meet the expectations of the community and provide a 
sufficiently high level of comfort for passengers, all of which may be provided by electric buses. This means that electric buses should have similar parameters as their combustion's counterparts. It is essential that during the design phase, the negative effects of charging the battery at the terminuses are minimized and therefore the purchased electric buses should be able to cover a typical urban route without the need for additional charging [5]. The second group of interested parties, the DSOs, will be responsible for ensuring the continuity of power supply to the charging points, both in the streets of the cities and in the depots. Previous studies pointed out potential problems in estimating power demand due to temporary and uneven loads associated with charging electric vehicles $[4,8,9]$. Therefore, the development of electromobility in public transport should take place in a sustainable manner and with the participation of all interested parties. Certainly, the key to ensuring the sustainable development of electric buses in public transport is to adapt existing legislation to minimize legal and economic barriers that will prevent further electrification of public road transport.

This article analyses the impact of electric buses on the local distribution grid-in the nearest electric vicinity of the bus terminus with installed charging infrastructure. In previous studies in this field [8-14], the focus was placed on simulation models with a daily load curve, most often for the whole city. However, the authors noted that the results of simulation models (based on schedules data) have not yet been compared with actual measurements carried out at such a charging point for electric buses. Additionally, the authors conducted measurements of the power quality parameters at the substation as an element of the distribution network. The voltage total harmonic distortion $\left(\mathrm{THD}_{\mathrm{U}}\right)$ factor was analysed as well as the character of the pantograph charging point operation. Based on the conducted research it is possible to fill the knowledge gap concerning the influence of the chargers on the nearest electric vicinity of the bus terminus with the chargers installed. This approach is critical due to the ongoing electrification of public transport. As a result of the research, DSOs will be able to use the results of the analysis to design distribution networks in the vicinity of such a terminus. The proposed algorithm for calculating the impact of chargers on the network is universal for each bus terminus, as it requires further calculation values dependent on bus traffic. It should be stressed that the analyses carried out during the studies in question concerned the legal conditions applicable to Poland. It is worth mentioning that Warsaw, the capital of Poland, was adopted as the base city. Due to the economic potential of Warsaw, it can be assumed that it will be the most interesting subject of research in the case of electric bus implementation in public transport.

The paper is organized as follows: Section 2 provides a forecast of the number of buses in Warsaw, which shows the scale of the problem of public transport electrification in a large city. Section 3 presents the methodology of creating a bus terminus model with charging points, and Section 4 presents the results of a simulation of the created bus terminus in Warsaw. Section 5 summarizes the obtained results and presents conclusions.

\section{Forecast of Growth in the Number of Electric Buses in Warsaw}

To discuss the development of electromobility in public transport and to examine its impact on the power system, a bus network in Warsaw, the capital of Poland, was used. There are several bus operators in Warsaw, however, the largest operator is a company called MZA (Miejskie Zakłady Autobusowe, Warsaw, Poland). Their fleet consists of 1360 buses. The remaining carriers operating in Warsaw have about 300 buses in total. In order to simplify the analysis, it was assumed that the development of electromobility in public transport would take place only in the case of MZA. It should also be emphasized that the Act of 11 January 2018 on Electromobility and Alternative Fuels [15] is in force in Poland. It imposes an obligation on communes and counties with a population of more than 50,000 people to have public transport, in which by $2028,30 \%$ of all buses used in a particular area must be zero-emission, i.e., electrically powered. Therefore, the forecast of the number of electric buses planned to be used in Warsaw was made. This is shown in Figure 1.

The forecast includes data on electric buses already ordered (blue bars). Based on data from years 2015-2020 about the purchased and planned to purchase buses [16], an estimation of the number of 
electric buses was made. The estimated number of buses $N_{E B}$ in year $t$ was determined using a linear regression method, which is presented by (1) [17]. The input data are presented in Table 1.

$$
N_{E B, t}=\hat{\alpha}+\hat{\beta} t
$$

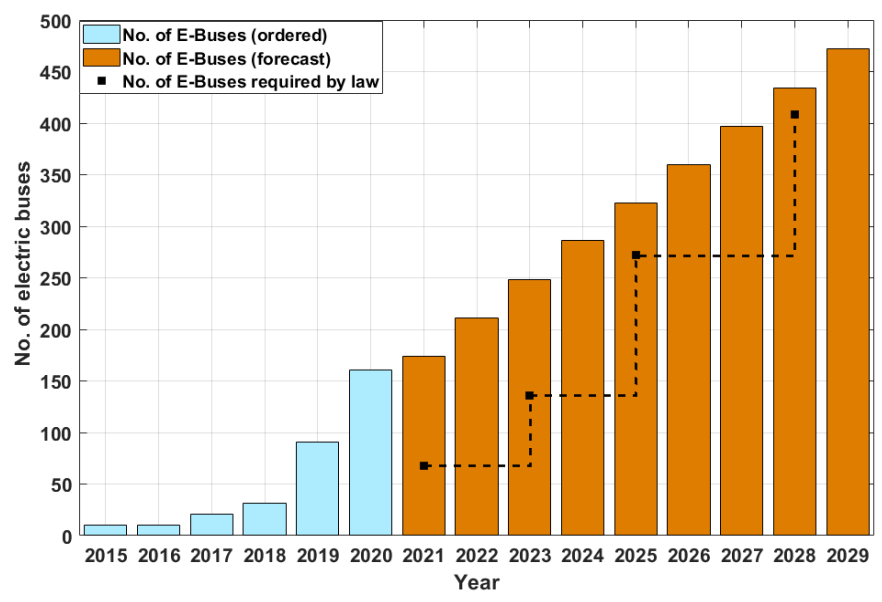

Figure 1. Forecast of the number of electric buses in Warsaw, based on $[16,18]$.

Table 1. Input data for forecast execution $[16,18]$.

\begin{tabular}{cccc}
\hline $\boldsymbol{i}$ & Year, $\boldsymbol{t}_{\boldsymbol{i}}$ & $\begin{array}{c}\text { New Registration } \\
\text { no. of Electric Buses }\end{array}$ & $\begin{array}{c}\text { Total No. of Electric } \\
\text { Buses, } \boldsymbol{N}_{\boldsymbol{E}, \boldsymbol{i}, \boldsymbol{i}}\end{array}$ \\
\hline 1 & 2015 & 10 & 10 \\
2 & 2016 & 0 & 10 \\
3 & 2017 & 11 & 21 \\
4 & 2018 & 10 & 31 \\
5 & 2019 & 60 & 91 \\
6 & 2020 & 70 & 161 \\
\hline
\end{tabular}

$\hat{\alpha}$ and $\hat{\beta}$ are the explanatory variables, determined according to Equations (2) and (3) [17].

$$
\begin{gathered}
\hat{\beta}=\frac{\sum_{i=1}^{n}\left(t_{i}-\bar{t}\right) \cdot\left(N_{E B, i}-\overline{N_{E B}}\right)}{\sum_{i=1}^{n}\left(t_{i}-\bar{t}\right)^{2}} \\
\hat{\alpha}=\overline{N_{E B}}+\hat{\beta} t
\end{gathered}
$$

where: $i$-number of successive values from $n$-elements statistical data sample; $t_{i}$-year of operation of the electric buses from statistical data; $N_{E B i}$-number of electric buses operated in year $t_{i}$.

The points colored in black in Figure 1 indicate the increase in the number of electric buses with the assumption of objectives imposed by the Polish Electromobility Act [15]. The forecast assumes that the targets set will be met in 2028. Interestingly, during the first years of the implementation of electric public bus transport to Warsaw, the number of buses delivered or planned to be delivered will exceed requirements provided by the Act. This is a good prognosis of the process of electrification of public bus transport without potential perturbation. However, it should be noted that the process of transport electrification will only be possible when sufficient financing is provided for such investments. Incorrect financial management may result in the inability to meet the conditions of the Act. Based on the data provided by MZA [19], it has planned to electrify 12 bus lines and to place pantograph quick charging points at 17 terminuses. 


\section{Methodology of Research}

In order to analyze in detail how the bus charging process affects the local power infrastructure, a model of a bus terminus with installed chargers was created and then the results obtained in simulations were compared with the actual measurements at the bus charging point.

The measured charging point was located at Spartańska Street in Warsaw [20]. Currently, it serves most of the electric buses and is mainly responsible for charging the buses on line No. 222 . The parameters of the charging point are presented in Table 2, while Table 3 shows the functional data of line No. 222.

Table 2. Technical parameters of the charging point at Spartańska Street [21].

\begin{tabular}{ccccc}
\hline $\begin{array}{c}\text { Manufacturer and } \\
\text { Series }\end{array}$ & $\begin{array}{c}\text { Charging } \\
\text { Interface }\end{array}$ & $\begin{array}{c}\text { Maximal Power } \\
\text { Output } P_{C H}(\mathbf{k W})\end{array}$ & $\begin{array}{c}\text { Charging } \\
\text { Voltage } U_{C H}(\mathrm{~V})\end{array}$ & $\begin{array}{c}\text { Voltage Supply } \\
U_{A C}(\mathrm{~V})\end{array}$ \\
\hline $\begin{array}{c}\text { EkoEnergetyka } \\
\text { quickPOINT Column } \\
\text { Charger }\end{array}$ & $\begin{array}{c}\text { Pantograph-fast } \\
\text { charging system }\end{array}$ & 200 & $\begin{array}{c}200-800 \mathrm{~V} \text { DC } \\
\text { (BMS request) }\end{array}$ & $400 \mathrm{AC}$ \\
\hline
\end{tabular}

Table 3. Functional data of bus line No. 222.

\begin{tabular}{|c|c|c|c|c|}
\hline $\begin{array}{l}\text { No. of the Bus } \\
\text { Line }\end{array}$ & $\begin{array}{l}\text { Model of the } \\
\text { Electric Bus }\end{array}$ & $\begin{array}{c}\text { Energy } \\
\text { Consumption } u_{c} \\
(\mathbf{k W h} / \mathbf{k m})\end{array}$ & $\begin{array}{l}\text { Length of Bus } \\
\text { Route } l(\mathbf{k m})\end{array}$ & Frequency of Courses \\
\hline 222-Normal line & $\begin{array}{l}\text { Solaris Urbino } 12 \\
\text { Electric }(200 \mathrm{kWh})\end{array}$ & 1.5 & 10 & $\begin{array}{c}\text { Every } 15 \text { min in rush hours, } \\
\text { otherwise every } 20 \text { min }\end{array}$ \\
\hline
\end{tabular}

The research of the charging point at Spartańska Street was carried out with the use of a network analyzer, in compliance with the EN 50160 standard [22]. This meant that 10-min mean values were recorded during a week. The following parameters of the grid were examined: phase voltages-RMS, the minimum and maximum; active and reactive power; voltage and current total harmonic distortion factor THD; power factor $\cos \varphi$. The obtained measurement values will be used as base values in the bus terminus model proposed by the authors.

To compare the influence of the bus charging infrastructure on the grid, a model of the distribution network fragment with a planned electric bus charging station was used. The bus terminus was modeled in such a way that it met the assumptions developed by the MZA in Warsaw [19]. Those assumptions contain guidelines for the electrification of the existing Wilanów terminus. Three lines are planned for electrification: 116, 180, E-2. In the case of these lines, electric buses with a length of $18 \mathrm{~m}$ and a capacity $C$ of battery equal to $240 \mathrm{kWh}$ and an energy consumption $u_{c}$ equal to $1.8 \mathrm{kWh} / \mathrm{km}$ are going to be used. In the literature, the mentioned consumption often amounts to $1.3-1.5 \mathrm{kWh} / \mathrm{km}$, however, buses with a length of $12 \mathrm{~m}$ are most frequently used in the research $[3,11,23,24]$. Additionally, it should be noted that all three lines are quite long and their routes lead through areas with high traffic density. Detailed data of the mentioned lines are presented in Table 4. Figure 2 shows the electric scheme of the Wilanów terminus model. It should be noted that the electrical scheme shows in detail mainly the bus terminus. It is crucial for the analysis of the research problem. The work of the distribution network does not significantly affect the working conditions of the charging points on the terminus, while the work of the chargers may significantly affect the work of the distribution grid. In the research, the authors focused on showing the process of bus terminus connection, which is a load of high coupling power. 
Table 4. Data of electrified bus lines stopping at the Wilanów terminus.

\begin{tabular}{|c|c|c|c|c|}
\hline $\begin{array}{l}\text { No. of the } \\
\text { Bus Line }\end{array}$ & Model of the Electric Bus & $\begin{array}{c}\text { Energy } \\
\text { Consumption } \\
u_{c}(\mathrm{kWh} / \mathrm{km})\end{array}$ & $\begin{array}{c}\text { Length of } \\
\text { Bus Route } \\
l(\mathbf{k m})\end{array}$ & Frequency of Courses \\
\hline 116 & Solaris Urbino 18 Electric & 1.8 & 20.0 & Every $10 \mathrm{~min}$, throughout whole day \\
\hline 180 & Solaris Urbino 18 Electric & 1.8 & 19.5 & $\begin{array}{c}\text { Every } 10 \mathrm{~min} \text { in rush hours, } \\
\text { otherwise every } 12 \mathrm{~min}\end{array}$ \\
\hline E-2 & Solaris Urbino 18 Electric & 1.8 & 29.0 & Only in rush hours-every $10 \mathrm{~min}$ \\
\hline
\end{tabular}

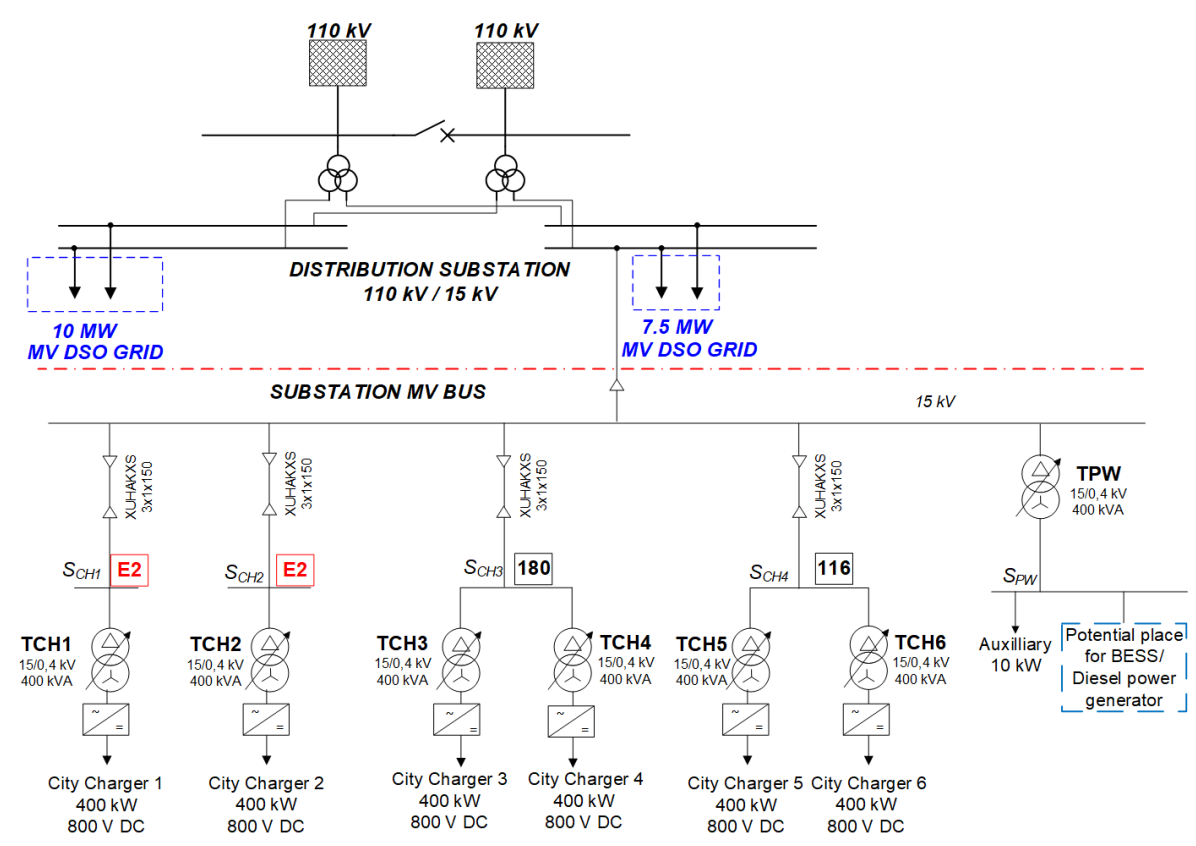

Figure 2. Electric scheme of the Wilanów terminus model for further analysis.

As the routes are longer and the frequency of courses is higher, the terminuses must be equipped with more powerful chargers than at Spartańska Street. Install $400 \mathrm{~kW}$ chargers has been planned. In addition, each bus line will be served by two chargers to ensure the redundancy. This means installing a total of six chargers. Their details are presented in Table 5. A similar case of installing six chargers was presented in the study [25], but it should be noted that in most cases one or two buses were loaded simultaneously at the same time. However, in the case of the Wilanów terminus model, the bus timetable was analysed. Considering the gap between the arrival of the next bus and the departure of the previous one of about $2 \mathrm{~min}$, the model, as mentioned earlier, used two chargers dedicated to each line. This not only provides equipment redundancy, but also robustness against schedule disturbances. This allowed for each charging point to work about three times per hour. It should also be emphasized that without a detailed analysis of the timetable, it is impossible to unequivocally determine how many charging points will be used. It is worth remembering that the worst possible case should be considered while analyzing the impact of bus charging on the distribution network.

Table 5. Technical parameters of charging points on the Wilanów terminus [21].

\begin{tabular}{cccc}
\hline Charging Interface & $\begin{array}{c}\text { Maximal Power } \\
\text { Output } \boldsymbol{P}_{C H}(\mathbf{k W})\end{array}$ & Charging Voltage $U_{C H}(\mathrm{~V})$ & Voltage Supply $U_{A C}(\mathrm{~V})$ \\
\hline $\begin{array}{c}\text { Pantograph-fast } \\
\text { charging system }\end{array}$ & $2 \times 400$ for each line & $200-800$ V DC (BMS request) & 400 AC \\
\hline
\end{tabular}


The basic parameter in the subjected analysis is the level of power demand. Hence, it should be considered on different levels. The first possibility of power demand analysis is to determine the daily curve based on the average hourly power $P_{1 h, t}$. In the conducted research, averaged values measured at the actual charging point at Spartańska Street in Warsaw and power values obtained in the Wilanów terminus model were used.

Assuming a time interval of $1 \mathrm{~h}$, the average energy consumed by the chargers per hour was obtained. Assuming hourly energy consumption values, calculation of the energy consumed by the chargers throughout the day has been made, according to Equation (4).

$$
E_{d}=\int_{t=0}^{24} P_{t} d t=\sum_{t=1}^{24} P_{1 h, t}
$$

where $P_{1 h, t}$ is calculated according to Equation (5).

$$
P_{1 h, t}=\frac{\int^{T} P_{C H, t} d t}{T}
$$

where $T$ is the period of one hour for which the average value is determined.

It is crucial for the functioning of electric public transport to spot the difference between the average hourly power $P_{1 h, t}$ and the value of the instantaneous power consumed by the charger $P_{C H, t}$. Taking into account this information as well as knowledge about the length of routes and technical data of the buses, the maximum power values of the Wilanów terminus were calculated. The methodology of calculating those values for a single charging point is presented below using Equations (6)-(8):

$$
E_{\text {remain }}=S O C_{M A X} \cdot C-D_{T R I P}=S O C_{M A X} \cdot C-l \cdot u_{c}
$$

where: $E_{\text {remain }}$-energy stored in the batteries of the bus after driving its route, in $\mathrm{kWh} ; S_{\mathrm{N}} \mathrm{C}_{\mathrm{MAX}}$-State Of Charge (SOC) at the beginning of the journey, in $\mathrm{kWh} ; \mathrm{C}$ - battery capacity, in $\mathrm{kWh} ; D_{T R I P}$ - electricity consumed during the one bus trip

$$
E_{\text {repl }}=D_{\text {TRIP }}=l \cdot u_{c}
$$

where: $E_{\text {repl }}$ —energy that has to be replenished when charging on the terminus, in $\mathrm{kWh} ; u_{c}$ —energy consumption per $1 \mathrm{~km}$ driven, in $\mathrm{kWh} / \mathrm{km}$; l-length of the bus route between charging, in $\mathrm{km}$.

In the analyses it was assumed that the $S O C_{M A X}$ value was on average $90 \%$, as in [9]. This is due to the need to ensure a safe voltage level on individual battery cells during the charging process (protection against overcharging and battery failure).

$$
P_{C H}=\frac{D_{T R I P}}{T_{S T O P_{a v g}}}
$$

where: $P_{C H}$-maximum charging power of the bus, in $\mathrm{kW} ; T_{S T O P a v g}$-average time of the bus stopping on the terminus, in hours.

In practice, the aim should be to minimize the maximum charging power by adjusting the dwell times at the terminus [26]. Therefore, the value of stopping time should fulfill the relation defined by Equation (9).

$$
T_{\text {STOP }}=\max \left\{T_{\text {sched }}, T_{c h}\right\}
$$

where: $T_{\text {sched }}$-time of stopping due to the schedule, in hours; $T_{c h}$-time of stopping needed to recharge the bus, in hours. 
Therefore, the $T_{\text {STOPavg }}$ value was calculated as follows:

$$
T_{S T O P_{\text {avg }}}=\sum_{i=1}^{n} T_{S T O P} \cdot \frac{1}{n}
$$

where: $n$-number of charges per day; $i-$ number of consecutive charges.

In order to determine the impact of the charging station, installed on the bus terminus, on the power quality at the substation, the sources of higher current harmonics must first be identified. In the proposed model, such sources were chargers that generate higher harmonics in the conversion of AC current to DC current. The authors proposed to include in the charger model the values of harmonic currents $I_{h}$ (11) [27], which were collected during measurements with a power analyzer-Hioki 3196.

$$
I_{h}=A_{h} \sin \left(h \omega t+\alpha_{h}\right)
$$

where: $A_{h}$-amplitude of the harmonic current; $\alpha_{h}$-phase angle of $h$-th harmonic.

Next, the load flow analyses were performed, considering the higher current harmonics of the chargers, in the DIgSILENT PowerFactory software. It was necessary to define the relation of the higher harmonic current to its fundamental, for odd harmonics. The ratio was defined according to Equation (12).

$$
d_{h}=\frac{I_{h}}{I_{1}}
$$

where: $h$-higher odd harmonic number: $h \in<3,39>$; $I_{1}$ —value of fundamental current.

Based on the input data, current total harmonic distortion $\left(T H D_{I}\right)$ and voltage total harmonic distortion $\left(T H D_{U}\right)$ were calculated according to Equations (13) and (14) [28].

$$
\begin{aligned}
T H D_{U} & =\frac{\sqrt{\sum_{h=2}^{40} U_{h}^{2}}}{U_{1}} \\
T H D_{I} & =\frac{\sqrt{\sum_{h=2}^{40} I_{h}^{2}}}{I_{1}}
\end{aligned}
$$

where: $U_{h}$-RMS value of voltage $h$-th harmonic; $U_{1}$-voltage RMS value of main frequency $(50 \mathrm{~Hz})$; $I_{h}$-RMS value of current $h$-th harmonic; $I_{1}$ —current RMS value of main frequency $(50 \mathrm{~Hz})$.

In the proposed model, the $T H D_{U}$ value will be measured on the busbar, to which chargers are connected and on the main busbar of the bus terminus, while the $T H D_{I}$ value will be measured on transformers connecting the medium voltage main busbar with the bus charger.

All in all, the proposed algorithm will enable a comprehensive assessment of the impact of charging stations on the substation in the distribution grid. The block diagram of the algorithm is presented in Figure 3. 


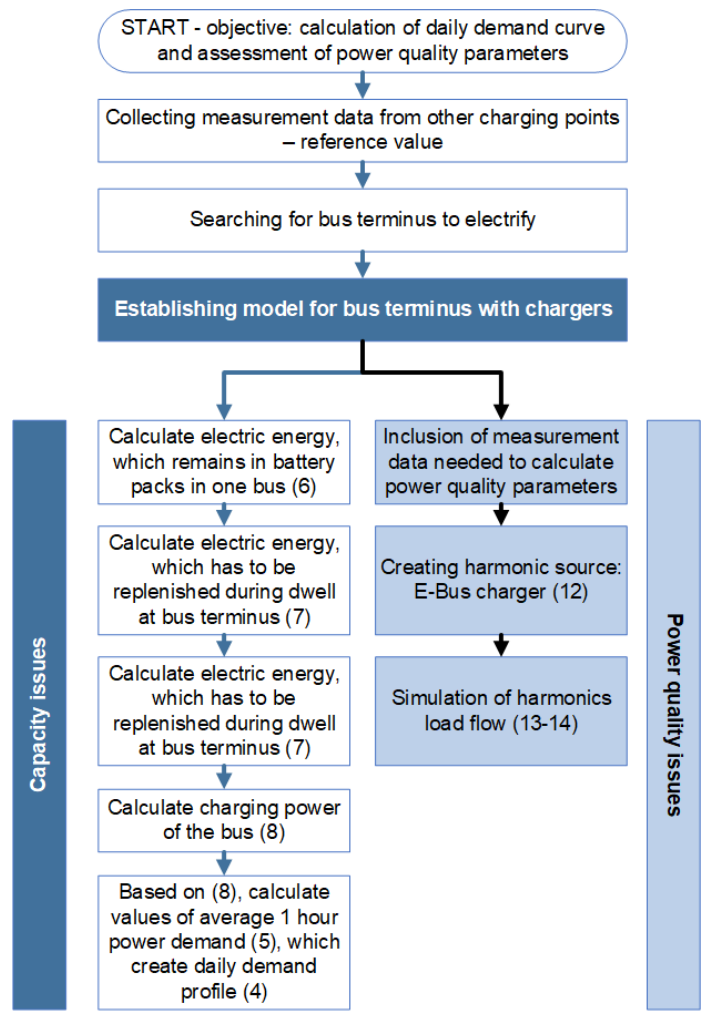

Figure 3. Block diagram of the electrification process of the bus terminus.

\section{Results-Case Study of Warsaw}

This section of the article presents the results for the Wilanów terminus model in the context of the problems with the functioning of the local power infrastructure with installed charging stations for electric buses. In order to find the influence of charging points on the distribution network, two objects were compared-the existing pantograph charging point and the model of the planned bus charging station connected to the MV network [20]. The first analysed aspect was the examination of the daily power demand profile. It is presented in Figure 4.

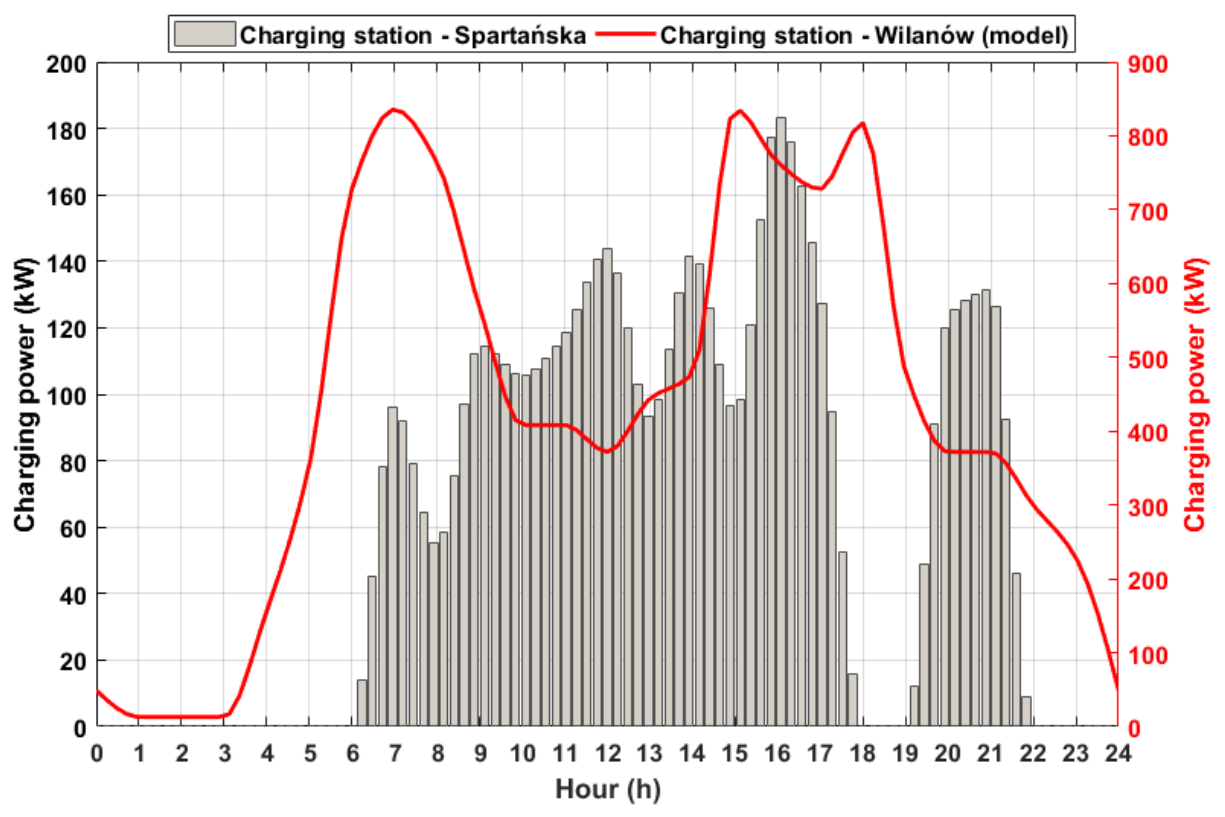

Figure 4. Daily power demand curve of charging points for electric buses. 
From the analysis of Figure 4, it can be stated that the daily demand profile for the power of the charging point at Spartańska Street was consistent with the profiles used in other cities [8]. It should be noted, however, that the profile of the Wilanów terminus, based mainly on assumptions resulting from bus schedules, differed from the actual applications. This may have resulted from the fact that on the Wilanów terminus, buses that operate only during peak hours are serviced. For instance, it was observed that the values of the load declined significantly between 10:00 and 14:00. If E-2 buses were running all day long, the daily profile of power demand would practically coincide with the real-life curves. This confirmed the validity of the Wilanów terminus modelling methodology. The difference between the profiles was also noted around 21:00. Then, there was a cycle of charging buses at the Spartańska charging point after an hour-long break. According to the assumptions of traffic on the Wilanów terminus, there was no break between 18:00 and 19:00, as in the case of the Spartańska charging point. The energy demand per day at the Spartańska charging station and at the planned Wilanów terminus was then calculated from Equations (4) and (5). It amounted to $544.49 \mathrm{kWh}$ at the Spartańska charging station and 10,549.81 kWh at the Wilanów terminus, respectively. This confirmed that the model was made correctly, as the values of load for the Wilanów terminus were proportional to the actual measurements made at Spartańska.

In order to analyze more precisely the bus charging process, the power consumed by the charger at Spartańska Street, within a 10-min interval, was measured. Figure 5 shows this measurement. The power values shown in Figure 5 indicate the actual bus charging profile during $1 \mathrm{~h}$ of the day. This was necessary to show the difference between the average hourly output and the maximum charging power of the bus. In the case of the Wilanów terminus, a number of simulations were performed, which allowed for the calculation of the maximum power of bus charging according to Equation (8). The calculation of such values would be equivalent to the measured power of $10 \mathrm{~min}$. The results are shown in Table 6.

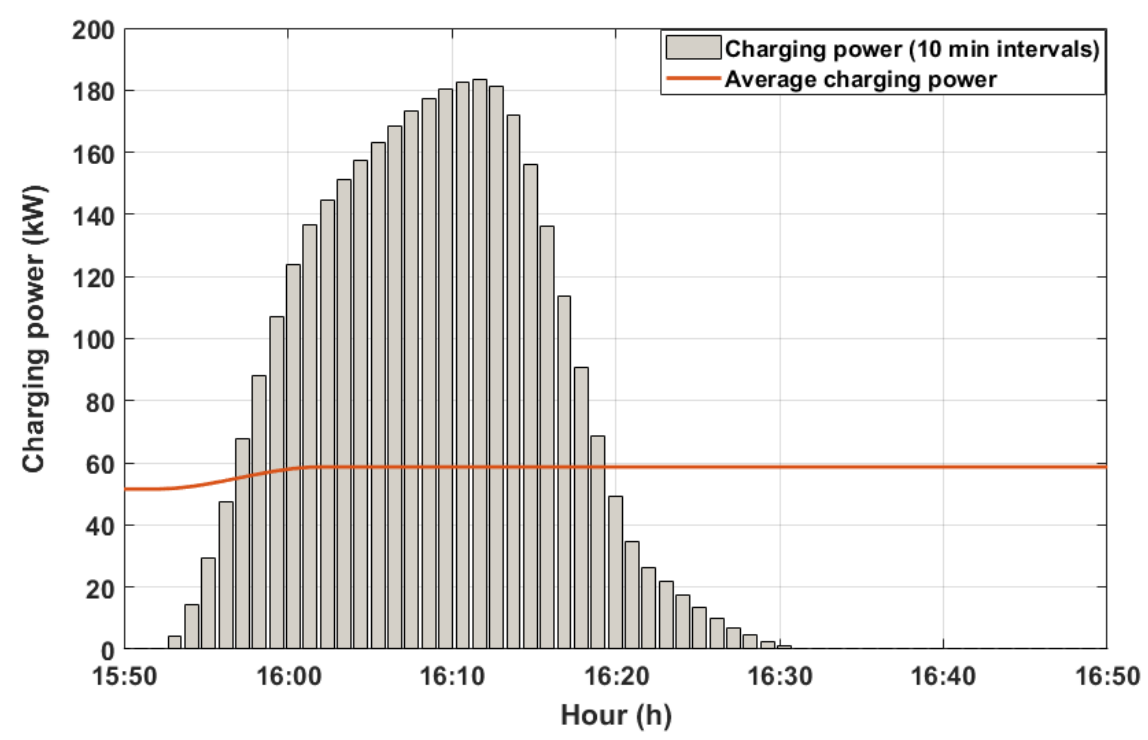

Figure 5. Hourly charging profile of electric buses at Spartańska Street charging station.

Table 6. Maximum power of bus charging on the Wilanów terminus.

\begin{tabular}{|c|c|c|c|c|c|}
\hline $\begin{array}{l}\text { No. of the } \\
\text { Bus Line }\end{array}$ & $\begin{array}{c}\text { Battery } \\
\text { Capacity } C\end{array}$ & $\begin{array}{c}\text { Energy } \\
\text { Consumption } \\
u_{c}(\mathrm{kWh} / \mathrm{km})\end{array}$ & $\begin{array}{l}\text { Stopping Time } \\
T_{\text {STOPavg }}(\mathrm{h})\end{array}$ & $\begin{array}{l}\text { Length of Bus } \\
\text { Route } l(\mathbf{k m})\end{array}$ & $\begin{array}{c}\text { Maximum } \\
\text { Charging Power } \\
P_{c h}(\mathbf{k W}) \\
\end{array}$ \\
\hline 116 & & & 0.18 (11 $\mathrm{min})$ & 20.0 & 198.81 \\
\hline 180 & $240 \mathrm{kWh}$ & 1.8 & $0.27(16 \mathrm{~min})$ & 19.5 & 131.89 \\
\hline $\mathrm{E}-2$ & & & $0.15(9 \mathrm{~min})$ & 29.0 & 353.32 \\
\hline
\end{tabular}


Calculations confirmed that the maximum charging power of electric buses could be much higher than the average value. This has an extremely high impact on the behavior of other network infrastructure elements, as a momentary overload with high power in the power system may result in a decrease in the quality parameters of electric energy. Assuming that all chargers, with maximum power, would operate simultaneously, the power demand for the Wilanów terminus would be $1.368 \mathrm{MW}$. Comparing this with the values obtained in Figure 4, we observed an increase of $65 \%$ in relation to average hourly power. This confirms that in order to properly design a bus terminus with integrated chargers, it is necessary to recalculate the maximum charging power.

Measurements made at the Spartańska charging point did not reveal any serious exceeding of the supply voltage parameters contained in the EN 50160 standard [22], which was already mentioned in previous studies [20]. One dangerous event was recorded, during which one of the phase voltage values fell below the limit, while the bus was being charged at the same time. This is shown in Figure 6 .

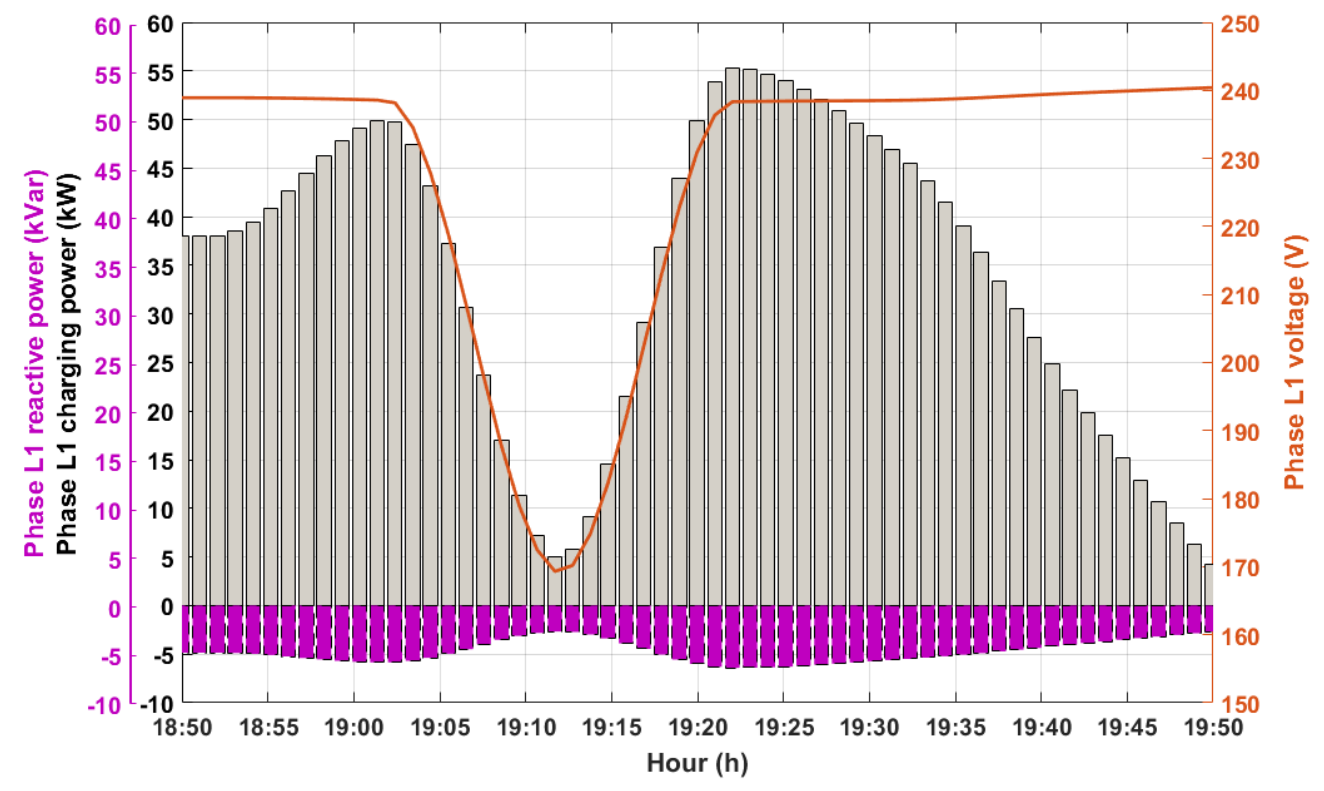

Figure 6. Voltage drop during bus charging at Spartańska Street charging point [19].

Measurements of the $T H D_{U}$ value at the Spartańska charging point did not indicate that the limit value was exceeded during the whole week-distortion of $2.5 \%$ was recorded. Therefore, the input data can be considered as accurate, and were therefore implemented into the bus terminus model in PowerFactory. Table 7 shows the $T H D_{U}$, phase voltage $U_{p h}$ and line-to-line voltage $U_{L-L}$ values observed in the measurements and obtained from the simulation-records from point of common coupling (PCC) of the charger and MV main substation. Figure 7 shows the voltage harmonic spectrum on the PCC of the charging station in the proposed model.

Table 7. Voltage parameters recorded during research.

\begin{tabular}{cccc}
\hline Parameter & $\begin{array}{c}\text { Spartańska } \\
\text { Charging Station }\end{array}$ & $\begin{array}{c}\text { Bus Terminus } \\
\text { Model-PCC }\end{array}$ & $\begin{array}{c}\text { Bus Terminus } \\
\text { Model-MV Substation }\end{array}$ \\
\hline$T H D_{U}$ & $1.89 \%$ & $4.06 \%$ & $3.42 \%$ \\
$U_{p h}$ & $240.11 \mathrm{~V}$ & $230 \mathrm{~V}$ & $9.02 \mathrm{kV}$ \\
$U_{L-L}$ & $415.2 \mathrm{~V}$ & $400 \mathrm{~V}$ & $15.62 \mathrm{kV}$ \\
\hline
\end{tabular}




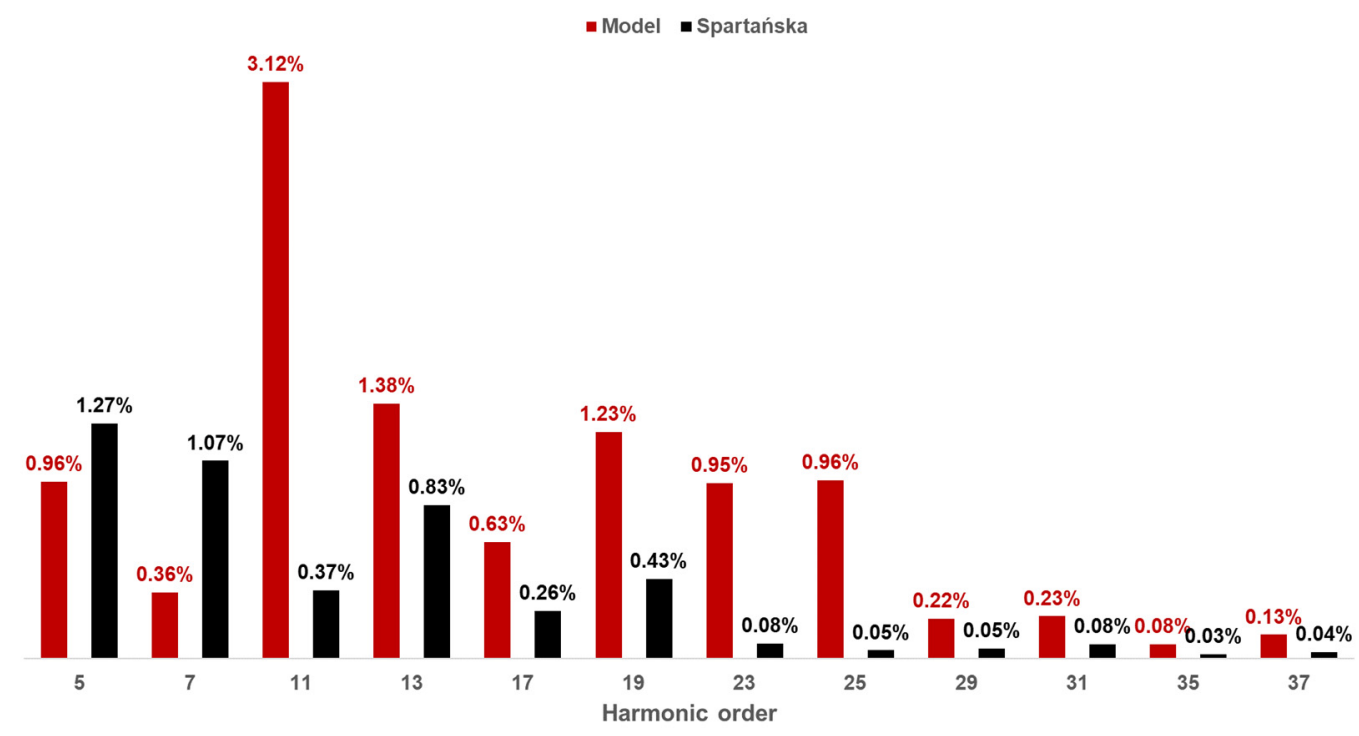

Figure 7. Voltage harmonic spectrum on the Spartańska charging station and on the PCC of the charger in the bus terminus model.

Based on Table 7, it can be concluded that $T H D_{U}$ in PCC in the Wilanów terminus model was significantly higher than in the case of actual measurements at the Spartańska charging station. This may be due to the characteristic point of operating conditions of the distribution grid in the Spartańska station electric vicinity. In the designed model, exemplary harmonic profiles for DSO network loads were assumed, which were previously defined in PowerFactory software. In order to verify and complete the data, power quality tests on MV stations in the DSO system should be developed. The difference in network operating conditions is also reflected in the recorded phase voltage values. At the Spartańska charging station, the voltage was $10 \mathrm{~V}$ higher than the nominal value and the values recorded in the model were equal to the nominal value. An important parameter is therefore the power factor $\cos \varphi$ of the charger. As can be seen from Figure 6, the Spartańska charging station has a capacitive character. The model also uses a power factor of a capacitive character, but the results obtained indicated quite a balanced operation of the grid. Based on Figure 7 it can be concluded that some of the harmonics were compensated in the DSO grid. In particular, the difference was visible in the 11th and 19th harmonics. In addition, the $T H D_{I}$ value was measured in the model, on transformers connecting chargers with the busbar. It amounted to $4.10 \%$, while in measurements at the Spartańska charging station the value was $4.17 \%$.

\section{Conclusions}

This article presents an analysis of the impact of introducing a fleet of electric buses in Warsaw. The increase of power demand during a day was analyzed. The influence of electric bus charging on local parameters of electric power quality as well as technical strength of network infrastructure were studied. In order to verify the strength of the infrastructure, the maximum charging powers for individual chargers were calculated.

Analyzing the obtained results, it can be observed that no significant problems with the functioning of the local network infrastructure were found for the research assumptions. An important issue that may indicate the adverse impact of charging points for electric buses on the functioning of the local distribution network is the question of fulfilling the quality parameters of electric energy contained in the EN 50160 standard. Although no significant exceedances of quality parameters have been observed in the conducted studies, it should be borne in mind that each charger may have a different topology of power electronic systems. Therefore, the results concerning the quality parameters of electric energy 
at the given points may differ from each other. When analyzing voltage amplitudes, the nature of the distribution network to which the charger is connected should also be considered.

When analyzing the development of electromobility in the public sector, measures can be proposed to minimize the negative impact of charging electric vehicles. The first way could be to optimize the charging process of electric buses by influencing stopping times and thus charging times. However, it requires interdisciplinary action in both transport logistics and the power engineering sector. The second way to reduce the negative impact of charging electric buses on the power grid may be to use local energy storage (e.g., Li-ion batteries) and to support them with distributed generation sources [29]. Such a solution is the basis for the creation of modern, intelligent power grids in which sustainable public transport consists of zero-emission vehicles. It should not be forgotten, however, that the creation of a Smart Grid does not consist exclusively on the installation of distributed generation sources supporting the work of chargers, but also in a modern system of metering and diagnostics, and in the order of dynamic control of the work of future distribution networks. Charging a large number of electric buses may disrupt the continuity of electricity supply, therefore smart metering in cooperation with advanced switching automatics is necessary to carry out appropriate switching operations in the network so as not to deteriorate the indicators of continuity of energy supply to the end user $[20,30]$. Both proposals to minimize the impact of the introduction of electric public bus transport on the power grid are a good starting point for the introduction of the idea of energy efficiency in urban agglomerations.

Author Contributions: Conceptualization, K.Z. and M.K.; methodology, K.Z and J.P.; software, K.Z.; validation, P.M., M.B. and K.P.; formal analysis, P.T. and K.P.; resources, Ł.M.; data curation, M.B. and Ł.M.; writing-original draft preparation, K.Z and J.P.; writing — review and editing, J.P.; visualization, P.M.; supervision, J.P. All authors have read and agreed to the published version of the manuscript.

Funding: This research received no external funding

Conflicts of Interest: The authors declare no conflicts of interest.

\section{References}

1. International Energy Agency. Global EV Outlook 2018; IEA: Paris, France, 2018.

2. Rogge, M.; Van der Hurk, E.; Larsen, A.; Sauer, D.U. Electric bus fleet size and mix problem with optimization of charging infrastructure. Appl. Energy 2018, 211, 282-295. [CrossRef]

3. Kontou, A.; Miles, J. Electric Buses: Lessons to be Learnt from the Milton Keynes Demonstration Project. Procedia Eng. 2015, 118, 1137-1144. [CrossRef]

4. Steen, D.; Tuan, L.A. Impacts of Fast Charging of Electric Buses on Electrical Distribution Systems. In Proceedings of the 24th International Conference \& Exhibition on Electricity Distribution (CIRED), Glasgow, UK, 12-15 June 2017. [CrossRef]

5. Mahmoud, M.; Garnett, R.; Ferguson, M.; Kanaroglou, P. Electric buses: A review of alternative powertrains. Renew. Sustain. Energy Rev. 2016, 62, 673-684. [CrossRef]

6. Laib, F.; Braun, A.; Rid, W. Modelling noise reductions using electric buses in urban traffic. A case study from Stuttgart, Germany. Transp. Res. Procedia 2019, 37, 377-384. [CrossRef]

7. Qin, N.; Gusrialdi, A.; Brooker, R.P.; T-Raissi, A. Numerical analysis of electric bus fast charging strategies for demand charge reduction. Transp. Res. Part A 2016, 94, 386-396. [CrossRef]

8. Rogge, M.; Wollny, S.; Sauer, D.U. Fast Charging Battery Buses for the Electrification of Urban Public Transport-A Feasibility Study Focusing on Charging Infrastructure and Energy Storage Requirements. Energies 2015, 8, 4587-4606. [CrossRef]

9. Mohamed, M.; Farag, H.; El-Taweel, N.; Ferguson, M. Simulation of Electric Buses on a Full Transit Network: Operational Feasibility and Grid Impact Analysis. Electr. Power Syst. Res. 2017, 142, 163-175. [CrossRef]

10. Gallet, M.; Massier, T.; Hamacher, T. Estimation of the energy demand of electric buses based on real-world data for large-scale public transport networks. Appl. Energy 2018, 230, 344-356. [CrossRef]

11. Xylia, M.; Leduc, S.; Patrizio, P.; Kraxner, F.; Silveira, S. Locating charging infrastructure for electric buses in Stockholm. Transp. Res. Part C 2017, 78, 183-200. [CrossRef] 
12. Lin, Y.; Zhang, K.; Shen, Z.; Ye, B.; Miao, L. Multistage large-scale charging station planning for electric buses considering transportation network and powergrid. Transp. Res. Part C 2019, 107, 423-443. [CrossRef]

13. Palomino, A.; Parvania, M. Advanced charging infrastructure for enabling electrified transportation. Electr. J. 2019, 32, 21-26. [CrossRef]

14. Boonraksa, T.; Paudel, A.; Dawan, P.; Marungsri, B. Impact of Electric Bus Charging on the Power Distribution System a Case Study IEEE 33 Bus Test System. In Proceedings of the IEEE PES GTD Grand International Conference and Exposition Asia (GTD Asia), Bangkok, Thailand, 19-23 March 2019. [CrossRef]

15. Polish Act on Electromobility and Alternative Fuels. January 11, (Dz. U. 2018, poz. 317); 2018. Available online: http://prawo.sejm.gov.pl/isap.nsf/download.xsp/WDU20180000317/T/D20180317L.pdf (accessed on 5 March 2020).

16. ZeEUS Local Brochure-Warsaw. Available online: http://zeeus.eu/uploads/publications/documents/zeeuscity-sheet-warsaw-en-final.pdf (accessed on 5 March 2020).

17. Sheldon, M. Ross., Introductory Statistics; Academic Press: Cambridge, MA, USA, 2005.

18. Program E- Bus: Polish Electric Bus; Ministry of Industry and Technology: Warsaw, Poland, 2017.

19. Kuźmiński, J. Koszty Eksploatacji Autobusów Elektrycznych (Operating Costs of Electric Buses); Miejskie Zakłady Autobusowe: Warsaw, Poland, 2017. (In Polish)

20. Kłos, M.; Zagrajek, K.; Biczel, P.; Sosnowski, Ł. Problematyka przyłączania do sieci dystrybucyjnej stacji ładowania autobusów elektrycznych (Issues related to the connection to the distribution network of electric bus charging stations). Przeglad Elektrotechniczny 2019, 1, 0033-2097. (In Polish)

21. Technical Data of quickPOINT City Charger, EkoEnergetyka. Available online: https://ekoenergetyka.com. $\mathrm{pl} / \mathrm{pl} /$ products/city-charger/ (accessed on 5 March 2020).

22. Standard EN 50160:2010, Voltage Characteristics of Public Distribution Systems. Available online: http: //copperalliance.org.uk/uploads/2018/03/542-standard-en-50160-voltage-characteristics-in.pdf (accessed on 5 March 2020).

23. Hagberg, M.; Roth, A.; Bäckström, S. Analys av Biogas Till el för Bussdrift Och Biogas Som Bränsle Till Bussdrift i Stadstrafik, Report C 171, Svenska Miljöinstitutet. Available online: https://docplayer.se/23369407Analys-av-biogas-till-el-for-bussdrift-och-biogas-som-bransle-till-bussdrift-i-stadstrafik.html (accessed on 5 March 2020).

24. Vepsäläinen, J.; Kivekäs, K.; Otto, K.; Lajunen, A.; Tammi, K. Development and validation of energy demand uncertainty model for electric city buses. Transp. Res. Part D Transp. Environ. 2018, 63, 347-361. [CrossRef]

25. Ding, H.; Hu, Z.; Song, Y. Value of the energy storage system in an electric bus fast charging station. Appl. Energy 2015, 157, 630-639. [CrossRef]

26. Xylia, M.; Leduc, S.; Patrizio, P.; Silveira, S.; Kraxner, F. Developing a dynamic optimization model for electric bus charging infrastructure. Transp. Res. Procedia 2017, 27, 776-783. [CrossRef]

27. Xiang, Y.; Cuk, V.; Cobben, J.F.G. Impact of Residual Harmonic Current on Operation of Residual Current Devices. In Proceedings of the IEEE 10th International Conference on Environment and Electrical Engineering, Rome, Italy, 8-11 May 2011.

28. Bosak, A.; Bosak, A.; Kulakovskyi, L.; Oboronov, T. Impact of EV Chargers on Total Harmonic Distortion in the Distribution System Network. In Proceedings of the IEEE 6th International Conference on Energy Smart Systems, Kyiv, Ukraine, 17-19 April 2019.

29. Kłos, M.; Marchel, P.; Paska, J.; Zagrajek, K.; Bielas, R.; Magdalena, B.; Łukasz, M.; Konrad, W. Forecast and impact of electromobility development on the Polish Electric Power System. In Proceedings of the E3S Web of Conferences, Pune, India, 18-20 December 2019; p. 84. [CrossRef]

30. Shahin, M.A. Smart Grid Self-healing Implementation for Underground Distribution Networks. In Proceedings of the Innovative Smart Grid Technologies-Asia (ISGT Asia), Bangalore, India, 10-13 November 2013.

(C) 2020 by the authors. Licensee MDPI, Basel, Switzerland. This article is an open access article distributed under the terms and conditions of the Creative Commons Attribution (CC BY) license (http://creativecommons.org/licenses/by/4.0/). 